\title{
高血圧患者血中lipoprotein(a) とそれに及ぼす降圧治療の影響
}

\author{
一特に nisoldipine について——
}

松 原三八夫* 渥美 剛* 浪岡勝彦**

\section{I. 緒 言}

動脈硬化惹起性物質として知られているlipoprotein(a) [Lp(a)] は虚血性心疾患 (IHD), 脳血管障害 (CVD) 等の 独立した重要な risk factor として確立されつつある ${ }^{1,2)}$. 一方高血圧 (HT) 患者は動脈硬化をきたしやすく, 前 2 疾患との合併も多い。さらにこれによく使用される $\mathrm{Ca}$ 拮抗剤は血管拡張, 降圧作用等に加光抗動脈硬化作用を も有することが指摘されている3)。そのためわれわれは HT 患者血中 $\mathrm{Lp}$ (a) とそれに及ぼす Ca 拮抗剤の 1 つで ある nisoldipine (バイミカード®)の影響につき検討を行 った.

\section{II. 方 法}

糖尿病, 腎不全, 肝疾患等合併のないWHO 分類 $\mathrm{I}$ ・ II 期の未治療 HT 患者男性 19, 女性 40 の計 59 名 (A 群; 32 74 歳, 平均 54 歳, 収縮期血圧は 160 212, 平均 174 $\mathrm{mmHg}$, 挔張期血圧は 92 132, 平均 $104 \mathrm{mmHg}$ ) におい て採血し， $3.8 \%$ クエン酸 $\mathrm{Na} 1 / 10$ 量を混和後血漿分離 し, 測定まで $-20^{\circ} \mathrm{C}$ に保存した. 比較のため同年代 のほぼ健常な男性 34, 女性 72 の計 106 名 (B 群; 30 75 歳, 平均 50 歳, 収縮期血圧は 102 148, 平均 $127 \mathrm{mmHg}$, 拡張期血圧は 56 88, 平均 $82 \mathrm{mmHg}$ ), 以前から降圧剂 にて治療中のコントロール良好な HT 患者男性 53, 女性 60 の計 113 名 ( $\mathrm{C}$ 群 : 33 74 歳, 平均 58 歳, 収縮期血 圧は 114 166, 平均 $144 \mathrm{mgHg}$, 拡張期血圧は 72 96, 平 均 $85 \mathrm{mmHg}$ ) からも同様に採血した. C 群患者に投与 中の降圧剤は nicardipine (60 mg/day), diltiazem $(90 \mathrm{mg})$,

\footnotetext{
*市立小樽病院内科

** 同 検查科
}

原稿受取日：1992年 11 月 25 日

採用決定日：1993年 1 月 21 日 nifedipine (30 40 mg) 等の Ca 怙抗剤 と captopril (37.5 $75 \mathrm{mg} /$ day), alacepril $(50 \mathrm{mg})$, delapril $(30 \mathrm{mg})$ 等の ACE 阻害剤の単独あるいは両者併用であった. 対象者中高脂 血症 (HL: IIa, IIb, IV 型), IHD (既往歴, 症状, ECG により診断), CVD (既往歷, 症状, 脳 CT スキャンによ り診断) 等を合併していた者の割合は Table 1 に示した ごとくであった.

次に A 群患者中 32 名に対し, nisoldipine 1 日 $10 \mathrm{mg} 2$ 分割投与を 4 6か月以上行い, 治療経過で同様に採血し た $(\mathrm{A}+\mathrm{Ni}$ 群 : 収縮期血圧は 120 176, 平均 $153 \mathrm{mmHg}$, 拡張期血圧は 68 104, 平均 $87 \mathrm{mmHg}$ と低下した).

血中 $\mathrm{Lp}(\mathrm{a})$ 測定は ELISA 法を用いた kit (Tint Elize Lp(a), Biopool 社, スェーデン) にて行ったが, その intra-, interassay variation はそれぞれ3.2, $8.3 \%$ であっ $た^{4)}$. 統計処理は $\mathrm{t}$ 検定, $\chi^{2}$ 検定を使用した.

\section{III. 結 果}

各群患者の血中 Lp(a) 值を Fig. 1 と Table 2 と示した が，A群患者の平均血中 $\mathrm{Lp}(\mathrm{a})$ は mean $\pm \mathrm{SE}$ で $19.1 \pm 2.2$ (1.1 101.0) $\mathrm{mg} / \mathrm{d} l$ であった. B 群では $11.8 \pm 0.8(0.2 \sim$ $46.1) \mathrm{mg} / \mathrm{d} l$ であり, C 群患者のそれは $14.1 \pm 1.2(0.4 \sim$ 76.0) $\mathrm{mg} / \mathrm{d} l$ であった. Lp(a) は生来 phenotype を認め, そのため血中值は遺伝的にある程度規定されているとさ れており, 元来正規分布をとらず対数変換することによ って正規分布となることがわかっている5).ゆえにこれ ら各群を対数変換した後に検定したが，それによるとA 群は B 群に比し有意に高值を示した $(\mathrm{p}<0.02)$. また A+ $\mathrm{Ni}$ 群では $\mathrm{Lp}(\mathrm{a})$ 平均值は $15.8 \pm 2.0(3.2 \sim 45.9) \mathrm{mg} / \mathrm{d} l$ と やや減少したが, 対数変換後の検定では B 群よりまだ高 かった $(\mathrm{p}<0.05)$.

次に動脈硬化の危険度が高くなるといわれている血中 $\mathrm{Lp}$ (a) $25 \mathrm{mg} / \mathrm{d} l$ 以上 ${ }^{6)}$ の高值例の割合は A 群で $28.8 \%$ で 
Table 1 The incidence of the various complications in subjects $(\%)$

\begin{tabular}{c|c|c|c|l} 
group & HL & IHD & CVD & \multicolumn{1}{|c}{ others } \\
\hline A & 20.3 & 10.2 & 3.4 & $\begin{array}{l}\text { cholelithiasıs, hemorrhoıds, } \\
\text { peptıc ulcer, } \\
\text { obesıty }\end{array}$ \\
\hline B & 17.0 & 0 & 0 & $\begin{array}{l}\text { common cold, psychosomatıc disorder, } \\
\text { hemorrhoids, chronıc gastritıs, } \\
\text { cholelıthiasıs, thyroıdal cyste, sımple goiter }\end{array}$ \\
\hline C & 31.0 & 15.0 & 4.4 & $\begin{array}{l}\text { cholelıthiasıs, psychosomatıc disorder, } \\
\text { obesity, peptıc ulcer, iron deficıency anemia, } \\
\text { thyroidal cyste, thyroıdal adenoma }\end{array}$ \\
\hline
\end{tabular}

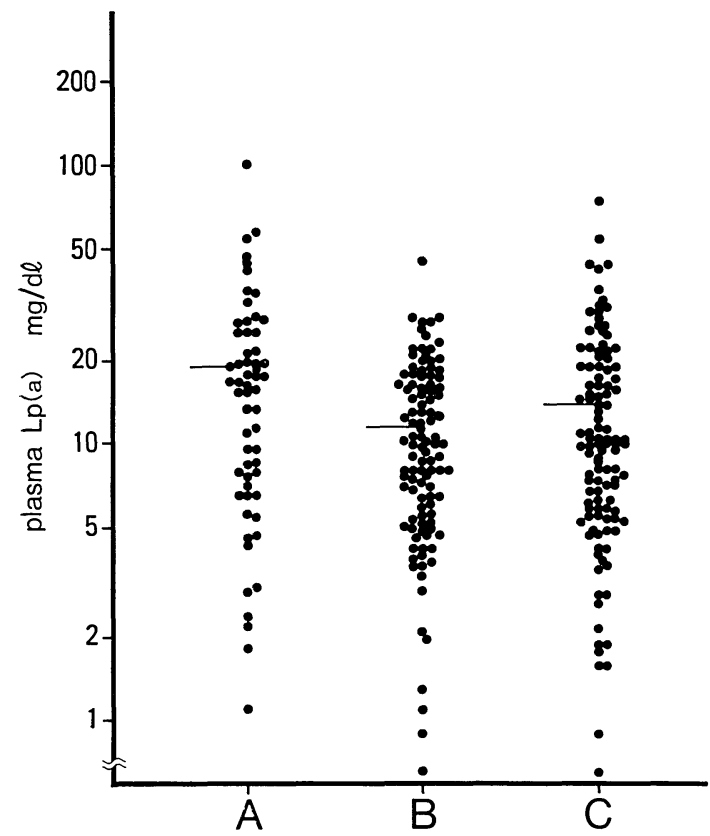

Fig. 1 Plasma $L p(a)$ levels in subjects.

Table 2 Mean plasma $\mathrm{Lp}$ (a) levels in each group subjects (mean \pm S.E.)

\begin{tabular}{|c|c|c|c|c|}
\hline group & $\mathrm{mg} / \mathrm{d} l$ & & $\log$ & \\
\hline A & $19.1 \pm 2.2 \overline{7}$ & \multirow{4}{*}{$P<005$} & $1.120 \pm 0.053$ & \\
\hline B & $11.8 \pm 0.8$ & & $0.961 \pm 0.035=$ & \\
\hline C & $14.1 \pm 1.2$ & & $0.998 \pm 0.037$ & $P<005$ \\
\hline $\mathrm{A}+\mathrm{N}_{1}$ & $15.8 \pm 2.0$ & & $1.100 \pm 0.058$ & \\
\hline
\end{tabular}

あり， B 群の $6.6 \%, \mathrm{C}$ 群の $14.2 \%$ に比し高頻度であっ た $(\mathrm{p}<0.001,0.025)$ 。 また $\mathrm{A}+\mathrm{Ni}$ 群では $15.6 \%$ で $\mathrm{C}$ 群 に近かった (Fig. 2).

$\mathrm{A}+\mathrm{Ni}$ 群の $\mathrm{Ni}$ 投与前後の血中 $\mathrm{Lp}$ (a) の変動を Fig. 3 に示したが，血中 $\mathrm{Lp}(\mathrm{a})$ 前值が $10 \mathrm{mg} / \mathrm{d} l$ 以下の者では

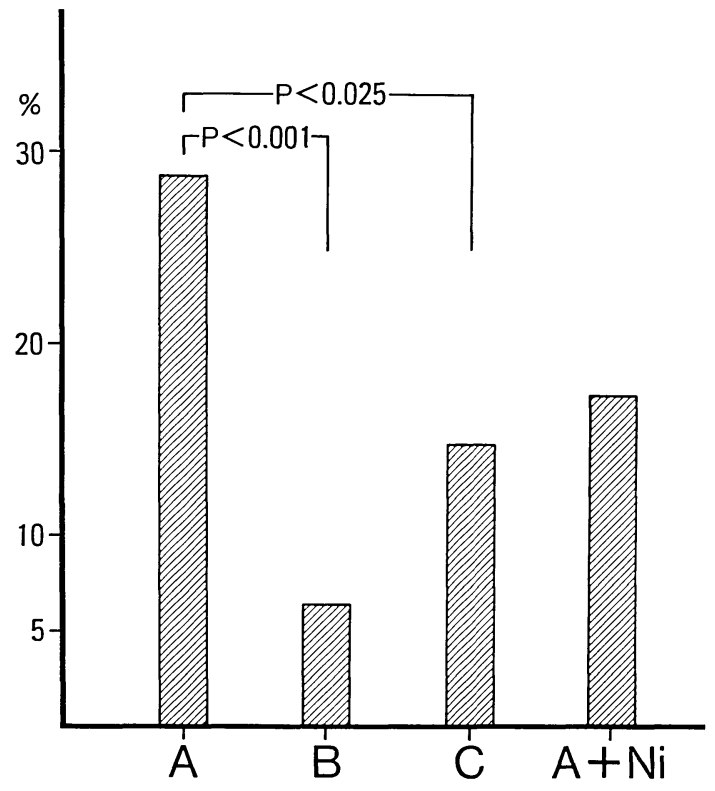

Fig. 2 The incidence of high $\mathrm{Lp}$ (a) levels above $25 \mathrm{mg} / \mathrm{d} l$ in each group subjects $(\%)$.

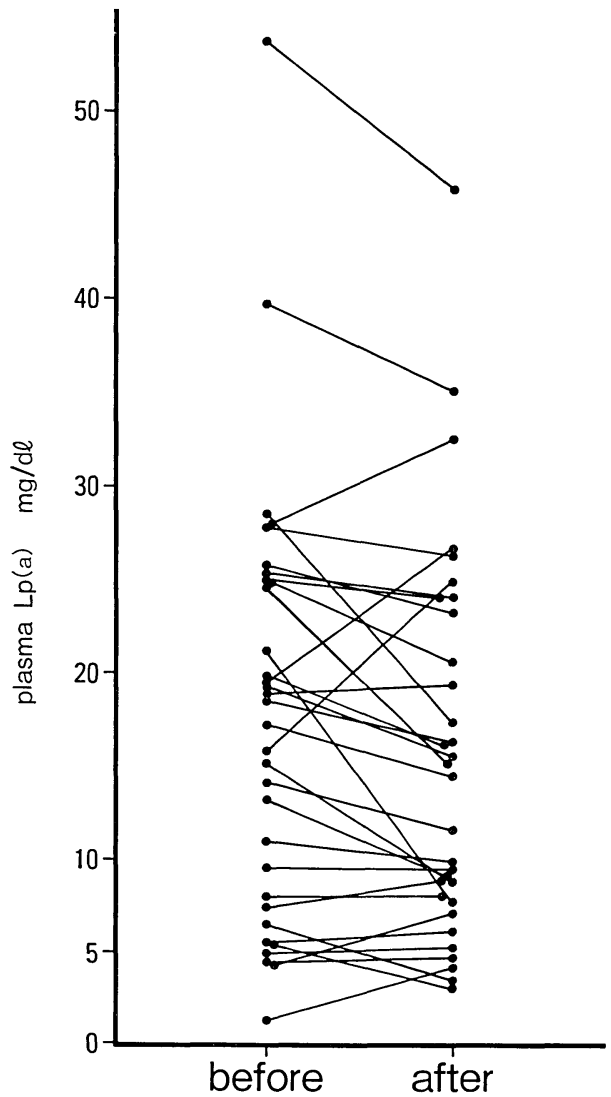

Fig. 3 Plasma $L p(a)$ levels in patients with group A before and after the administration of nisoldipine. 

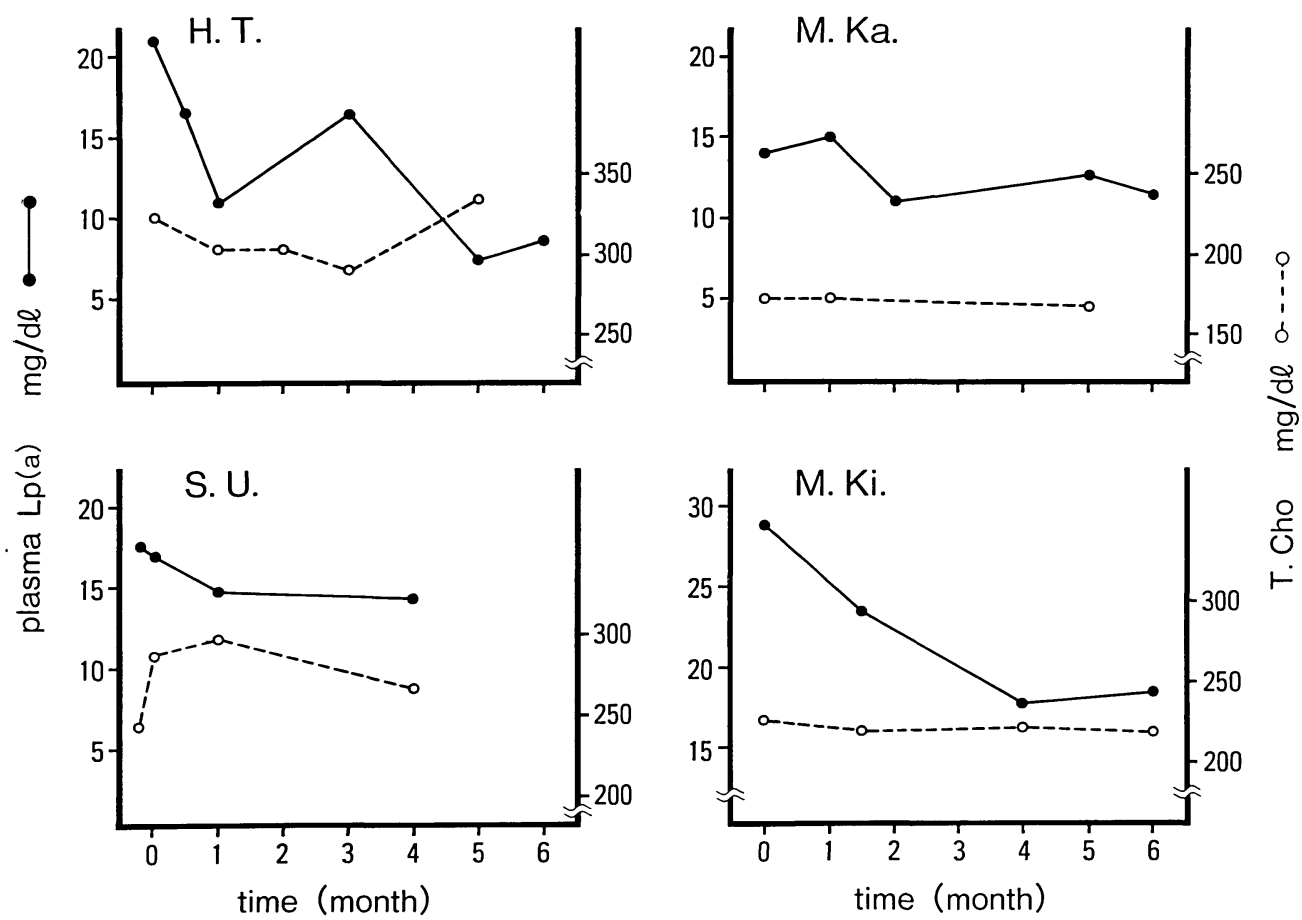

Fig. 4 The time course changes in typical 4 cases observed the decreased Lp(a) levels before and after the administration of nisoldipine.

低下がみられず，それ以上の者で多く低下する傾向がみ られた. うち典型的低下例の経時的変化を Fig. 4 に示し たが，T.Cho と無関係に Lp(a) は低下し数か月以内に プラトーに達するようにみえた。

\section{IV. 考 察}

対象者中未治療, 治療中高血圧患者である A ・ C 群は ほぼ同年代であり，また両群とも HL, IHD，CVD 等種々 合併症を有していたが，その頻度に差はなかった。これ らを同年代の軽症 HL, 感冒, 心因反応, 痔, 慢性胃炎, 甲状腺腫等を有する者を含む B 群健常者と比較したが， 後者では明らかな循環器疾患は認められなかった。

今回の研究により未治療高血圧で血中 Lp(a) は高值を 認め, 治療中のコントロール良好な患者では健常人と差 がないことが明らかとなった，その Lp(a) 高值を示す理 由として，高血圧では高 $\mathrm{Lp}(\mathrm{a})$ 血症をきたすことが知ら れている IHD, CVD等 ${ }^{1,2)}$ の合併が多いためその高值に より二次的に高值をとる可能性，あるいは本来 $\mathrm{Lp}$ (a) は 前 2 疾患に加え糖尿病, 慢性腎不全等の動脈硬化性疾患 で高值を示すことも知られており ${ }^{7,8)}$, 高血圧もその例外 ではないといら可能性等が考えられるが, 現時点で Lp(a) そのものの代謝, 病因的意義等が解明されていないため これを含めその詳細は今後の検討が必要であろう。
また高血圧治療中の患者で, 血中 $\mathrm{Lp}(\mathrm{a})$ は健常人と差 がないレベルまで低下していたが，その機序として， $\mathrm{Ca}$ 拮抗剤と ACE 阻害剂そのものの抗動脈硬化作用 ${ }^{3,9)}$ を介した低下，高血圧によるストレス状態が治療により 解除し全身状態が改善すること年により低下した，さら には高血圧でよくみられる IHD, CVD 等の合併症に Ca 拮抗剤，ACE 阻害剂が働いて ${ }^{11,12)} \mathrm{Lp}(\mathrm{a})$ 低下がもたら され二次的に低下してみえた可能性等が考えられるが， $\mathrm{Lp}$ (a) そのものの制御系が未だ不明のため, その解明の 過程でこれらも明らかになるものと推測される.1990年 Asplund らは高 $\mathrm{Lp}(\mathrm{a})$ 血症を認める CVD 患者は高血圧 の既往を有する者が多く，それは特に 65 歳以下の例で 顕著であったと報告した ${ }^{13)}$. 一方 Dahlén らは高血圧患 者で Lp(a) は正常であるとしたが，その血圧の程度，合 併症，治療の有無等は検討していなかった ${ }^{14)}$.

未治療高血圧への $\mathrm{Ni}$ 投与群では, 平均值, 高 $\mathrm{Lp}(\mathrm{a})$ 血症の割合とも治療中高血圧群と似ていたが，やや高い 傾向にあった. その差は, (1) Ni の量の不足, (2) Ni 単独 投与での血圧コントロール状況の関与, (3)両群の他疾患 合併状態の影響等のうちいずれによるものか不明であっ たが，血中 Lp(a) 前值が低い者ほど Ni による Lp(a) 低 下がみられない傾向にあった。

今回の対象の大半を占める, いわゆる本態性高血圧は 
家族性素因を有し, 中年以降に発症しやすいことはよく 知られた事実であり, 他方, 血中 $\mathrm{Lp}(\mathrm{a})$ も遺伝的にある 程度規定されていることが知られている ${ }^{15)}$. 高血圧のた めに血中 Lp(a) が高值を示すようになるのか，あるいは Lp(a) 高值例が高血圧をきたしやすいのか， 今後の検討 が必要であろう。

\section{V. 結 論}

1. 未治療高血圧で血中 Lp(a) は高值を示した.

2. 治療中高血圧では，未治療時より低下傾向にあり， Lp(a) は健常者と差がなかった.

3. 未治療高血圧への nisoldipine 投与でも Lp(a) は 低下傾向にあり, 特にその低下は $10 \mathrm{mg} / \mathrm{d} l$ 以上の例に 多かった.

本論文の要旨は 1992 年 6 月第 24 回日本動脈硬化学会 総会において発表した.

\section{文献}

1) Rhoads, G. G., Dahlén, G., Berg, K., Morton, N. E. and Dannerberg, A. L.: Lp(a) lipoprotein as a risk factor for myocardial infarction. J.A.M.A., 256: 2540-2544 (1986).

2) Woo, J., Lau, E., Lam, C. W. K., Kay, R., Teoh, R., Wong, H. Y., Prall, W. Y., Kreel, L. and Nicholls, M. G.: Hypertension, lipoprotein(a), and apoprotein A-I as a risk factors for stroke in the Chinese. Stroke, 22: 203-208 (1991).

3) Ouchi, Y., Akishita, M., Yabe, Y. and Orimo, H.: Effect of nifedipine on the progression of coronary atherosclerosis in humans. Jpn. Heart J., 32: 775-783 (1991).
4) 松原三八夫, 渥美 剛, 浪岡勝彦: 甲状腺機能六進 症患者の血中 lipoprotein(a) について. 日内分泌会 誌, 69: 556-561 (1993).

5) 安部彰: $\operatorname{Lp}(a)$. 医学のあゆみ, 157: 837-841 (1991).

6) Beisiegel, U., Niendorf, A., Wolf, K., Reblin, T. and Rath, M.: Lipoprotein(a) in the arterial wall. Eur. Heart J., 11 (Suppl. E): 174-183 (1990).

7) Takegoshi, T., Haba, T., Hirai, J., Kitoh, C., Saga, T., Yamazaki, Y. and Mabuchi, H.: Alteration of lipoprotein(a) in patients with diabetic nephropathy. Atherosclerosis, 83: 99-100 (1990).

8) Parra, H. J., Mazdour, H., Cachera, C., Dracon, M., Tacquet, A. and Fruchart, J. C.: Lp(a) lipoprotein in patients with chronic renal failure treated by hemodialysis. Clin. Chem., 33: 721 (1987).

9) Chobanian, A. V., Haudenschild, C. C., Nickerson, C. and Drago, R.: Antiatherogenic effect of captopril in the Watanabe heritable hyperlipidemic rabbit. Hypertension, 15: 327-331 (1990).

10) Maeda, S., Abe, A., Seishima, M., Makino, K., Noma, A. and Kawade, M.: Transient changes of serum lipoprotein(a) as an acute phase protein. Atherosclerosis, 78: 145-150 (1989).

11）菊地 均, 平盛勝彦: 冠動脈硬化症一 $\mathrm{Ca}$ 拮抗薬. 現代医療, 23: 1901-1904 (1991).

12) Walsh, W. F. and Lee, C. L.: Acute and long-term effects of captopril therapy in chronic heart failure. Asia Pacific Congress Series No. 21: p. 77 (Excerpta Medica, Amsterdam) (1983).

13) Asplund, K., Dahlén, G., Olsson, T. and Viitanen, M.: Lipoprotein(a) and its relation to hypertension in patients with acute stroke. Stroke, 21 (Suppl. I): I-91 (1990).

14) Dahlén, G. H.: Incidence of $L p(a)$ lipoprotein among population. In: Scanu, A. M. ed., Lipoprotein(a), San Diego, Academic Press, pp. 151-173 (1990).

15) Utermann, G.: The mysteries of lipoprotein(a). Science, 246: 904-910 (1989). 


\title{
Summary
}

\section{Plasma Lipoprotein(a) Levels in Patients with Hypertension, and the Effect of Nisoldipine to That Levels}

\author{
Miyao MatsubarA*, Tsuyoshi Atsumi* and Katsuhiko NAmioKA** \\ *Internal Medicine and ${ }^{* *}$ Laboratory Medicine, Otaru City General Hospital, Otaru, Japan
}

Lipoprotein(a) [Lp(a)] is known to provoke atherosclerosis and has been confirmed as a major independent risk factor for cardiovascular and cerebrovascular diseases. At the same time, patients with hypertension (HT) are prone to develop atherosclerosis. Calcium antagonists have been shown to have antiatherosclerotic properties in addition to their vasodilatory and antihypertensive effects. We therefore investigated the effect of nisoldipine $(\mathrm{Ni})$, a calcium antagonist, on plasma Lp(a) levels in HT patients.

(1) Plasma $\mathrm{Lp}$ (a) concentration was determined by ELISA for 59 (19 males and 40 females) untreated HT patients (group A; age: 32-74, mean 54 years) and found to be $19.1 \pm 2.2 \mathrm{mg} / \mathrm{d} l$ (Mean \pm S.E.: range from 1.1 to 101.0). This was higher than the value of $11.8 \pm 0.8$ (range from 0.2 to 46.1 ) determined for 106 ( 34 males and 72 females) healthy subjects in the same age range (group $\mathrm{B}$; age: $30-75$, mean 50 years, $\mathrm{p}<0.002$ ). In addition, there was a higher incidence of $\mathrm{Lp}$ (a) levels above $25 \mathrm{mg} / \mathrm{d} l$ in group A than in group B $(28.8 \%$ and $6.6 \%$, respectively; $\mathrm{p}<0.001$ ).
(2) The mean plasma $L p(a)$ level of 113 patients (53 males and 60 females) treated for HT with calcium antagonists and/or ACE inhibitors (group C; age: $33-74$, mean 58 years) was $14.1 \pm 1.2 \mathrm{mg} / \mathrm{d} l$ (range from 0.4 to 76.0 ). This value was lower than that of group $\mathrm{A}$ and was not significantly different from that of group B. $14.2 \%$ of group C had high (i.e. $>25 \mathrm{mg} / \mathrm{d} l$ ) $\mathrm{Lp}(\mathrm{a})$ levels, which was significantly lower than that of group A $(p<0.025)$, but not significantly different from group $B$.

(3) Following $\mathrm{Ni}$ administration to the $32 \mathrm{pa}-$ tients in group A, $\mathrm{Lp}$ (a) value for the group declined to $15.8 \pm 2.0 \mathrm{mg} / \mathrm{d} l$ (range from 3.2 to 45.9 ). The percentage of cases with high levels also decreased to $15.6 \%$, close to that for group C.

In conclusion, while high plasma Lp(a) levels were observed in group $\mathrm{A}$, group $\mathrm{C}$ tended to have levels lower than A and not different from B. Lp(a) levels in the $\mathrm{A}+\mathrm{Ni}$ group followed a similar pattern in group $\mathrm{C}$.

Key words: Hypertension, Lipoprotein(a), Calcium antagonist, Nisoldipine. 